\title{
Quantifying Ecosystem Service Supply, Social Demand and Their Link With Smallholder Farmers' Well-Being in Contrasting Agro-Ecological Zones of East African Rift Valley.
}

\section{Haile Ketema}

Nanjing Agricultural University

wu wei ( $\nabla$ ww@njau.edu.cn )

Nanjing University https://orcid.org/0000-0001-7335-2638

Abiyot Legesse

Dilla University

\section{Zinabu Wolde}

Nanjing Agricultural University

\section{Tenaw Endalamaw}

Dilla University

Aftab Ahmed Memon

Nanjing Agricultural University

\section{Research}

Keywords: agro-ecological zone, ecosystem service supply, social demand, supply-demand mismatch, subjective satisfaction, well-being indicator

Posted Date: March 2nd, 2021

DOI: https://doi.org/10.21203/rs.3.rs-253038/v1

License: (c) (1) This work is licensed under a Creative Commons Attribution 4.0 International License. Read Full License 
Quantifying ecosystem service supply, social demand and their link with smallholder farmers' well-being in contrasting agro-ecological zones of East African Rift Valley.

Haile Ketema ${ }^{1}$, Wu Wei ${ }^{1 *}$, Abiyot Legesse ${ }^{2}$, Zinabu Wolde ${ }^{3}$, Tenaw Endalamaw ${ }^{4}$ and Aftab Ahmed Memon ${ }^{5}$

${ }^{1}$ College of Land Management, Nanjing Agricultural University, 210095 Nanjing, China. (e-mail: haileketema2005@yahoo.com).

${ }^{2}$ Dilla University, College of Social Science, Department of Geography and Environmental Study, Ethiopia. (e-mail: abiyottura@gmail.com).

${ }^{3}$ College of Land Management, Nanjing Agricultural University, 210095 Nanjing, China. (e-mail: sos.zine04@gmail.com).

${ }^{4}$ Dilla University, College of Engineering and Technology, Department of Water Resources and Irrigation Engineering, Ethiopia. (e-mail: tenaw23@gmail.com)

${ }^{5}$ College of Public Administration, Nanjing Agricultural University, Nanjing 210095, China. (e-mail: aftabahmed32@gmail.com).

*Corresponding author: National and Local Joint Engineering Research Center for Rural Land Resources Use and Consolidation, 210095 Nanjing, China.

E-mail address: $\underline{w w @ n j a u . e d u . c n}$ 


\begin{abstract}
Background: Ecosystem service supplies (ES) have experienced progressive decline mostly due to increased ES social demand. Identifying ecosystem supply (ES), social demand, and their impacts on smallholder farmers' well-being is essential to ensure sustainable utilization of ES. Quantitative studies assessing ES mostly focused on ES supply with little attention given to social need and its effects on human well-being.
\end{abstract}

Methods: We assessed and mapped selected ES supply, social demand and their mismatches, and evaluated their impacts on subjective well-beings of smallholder farmers in contrasting agroecological zones (AEZ). We used a questionnaire survey to analyze and map six provisioning ecosystem services (ES) focusing on ES supply, social demand and their mismatches. Using the universal soil loss equation (USLE), we mapped the rate of soil loss in the contrasting agroecological zones (AEZ). A participatory approach was employed to evaluate smallholder farmers' well-being in the study region. Radar diagram was used to identify the links between ES supply, social demand and smallholder farmers' well-being.

Results: The results showed that a high supply of provisioning ecosystem goods such as cereal crops, fruits and coffee occurred in humid AEZ, while less supplies were seen in semi-arid AEZ of the study region. The ES supply was not in accordant with ES social demand and different factors such as population size and level of production are among the main factors causing ES supply-demand mismatches. Due to the undulating topography, high rate of soil loss was seen in humid AEZ. Smallholder farmers have given higher values for soil erosion control compared with individuals from semi-arid AEZ. Of all indicators of smallholder farmers well-being, 
income had the highest weight while receiving the least well-being satisfaction level both in humid and semi-arid AEZs.

Conclusion: The mismatches between supply and demand in provisioning ecosystem supply had strong and immediate impacts on smallholder farmers well-being. Therefore, we suggest policies that effectively control population growth, applying intensive crop production and strengthening integrated watershed management. These policies would help ES to recuperate and enhance its continuous flow and improve smallholder farmers' well-being both in the humid and semi-arid AEZ of the study region.

Keywords: agro-ecological zone; ecosystem service supply; social demand; supply-demand mismatch; subjective satisfaction; well-being indicator

\section{Introduction}

The benefits obtained from an ecosystem have attracted attention among different stakeholders worldwide [1, 2]. The economy of a nation is dependent on goods and services delivered by the ecosystem [3]. However, the increases in population and subsequent demand for economic development and urbanization have seriously affected multiple ecosystem services' temporal and spatial distribution (ES). Besides, the extent and intensity of societal dependency on ES have accelerated sharply than were in the past [2-4], recognizing the strong interaction between ES and human well-being. Since ES contribute to and shape well-being, requires an understanding of ES dynamics that the livelihood of the rural community depends on [2, 5-7]. However, lack of empirical evidence on the constitutes of well-being and its relationships with ES especially in the Sub-Saharan region limits the optimum utilization of ES supplies [8,9]. 
Studying the status of ES supply and demand in connection with human well-being becomes a vital cross topic in research worldwide [9-14]. To ensure the continuous flow of ES, ES must be consistently utilized in a sustainable manner that balance supply and demand [15]. Quantifying ES supply and demand have numerous benefits, among which, improving public awareness and alerting policymakers on how to manage contested resources are the most important ones. Moreover, it helps to know the cost of ES degradation and restoration, assist policy formulation and pave the way for sustainable ecosystem management [11, 12, 16-19]. Different countries have different environmental policies to reduce ES degradation and ensure sustainable management of social-ecological systems [15]. The mistranslation of these policies could cause a mismatch between ES supply and demand and becomes the main factor in causing unsatisfied demand $[9,20]$. Whenever there is no balance between ES supply and demand, the situation is said to be "mismatches" [7, 12, 15, 21]. The mismatch indicates the relationship between ES supply and demand [22]. However, most of the previous case studies had focused only on assessing the single ES supply-side, where the social demand-side and its impact on human well-being have been mostly ignored [23].

Due to population pressure in sub-Saharan Africa, it is believed to see an increasing mismatch between ES supply and demand over time and no exception for East African countries. Expansion of cultivated land in response to the increased population has further exacerbated the mismatch [11]. Most studies reported declining trends of ES supply over time due to LULC change $[11,24,25]$ contrary to alarmingly increasing ES demand. However, these studies lack ES demand-side and give little attention to mismatches' impacts on smallholder farmers' wellbeing. Therefore, understanding the ES supply-demand relationship is crucial to fill gaps created by mismatches and underpin human well-being improvements. Besides, recognizing the existing 
linkage between human well-being and ESs will increase the effort to prioritize ES management options and pave the way for effective implementation of relevant policies and programmes in the study region. Therefore, we aimed to address the following two research objectives:

To assess and map ES supply, demand, and mismatches in contrasting agro-ecological zones (AEZ).

To link ES supply-demand relationships with smallholder farmers' well-being along contrasting agro-ecological zones (AEZ).

Addressing these objectives will help to identify ES supply-demand sides, prioritize ES restoration and management to narrow gaps created by mismatches in a contrasting agroecological zone.

\section{Materials and Methods}

\subsection{Study area}

The study region is predominantly located in the Southeastern escarpment of Ethiopian Rift Valley, which lies between $6^{\circ} 10^{\prime} 0^{\prime \prime}$ to $6^{\circ} 30^{\prime} 0^{\prime \prime} \mathrm{N}$ and $38^{\circ} 0^{\prime} 0^{\prime \prime}$ to $38^{\circ} 30^{\prime} 0^{\prime \prime} \mathrm{E}$ (Figure 1). It is located inside the Great East Africa Rift Valley with a total area of 2,226.92 $\mathrm{km}^{2}$. Our study site includes six districts located in three political administrative regions, namely Southern Nation, Nationalities People Regional State (SNNPRS: Wonago, Bule, Yirgachefee, Dilla Zuriya districts), Sidama Region (Dara Districts) and Oromia Regional State (Abaya District) (Figure $1)$.

The altitude ranges from 1142 to $3017 \mathrm{~m}$ asl, comprising two different agro-ecological zones (AEZ) (Figure 1). The dominant characteristics of each AEZ are listed in Table 1. The interviewees' basic characteristics are summarized in the supplementary material (Table S1). 


\subsection{Research framework}

Given the supply-demand-side, we aimed to identify the links between ES supply, social demand and smallholder farmers' well-being in the contrasting agro-ecological zone (AEZ) (Figure 2). To do the links, six provisioning ES one regulating ES such as soil erosion control were selected. We then, mapped the provisioning ES supply, demand and their mismatches and modeled the biophysical ES supply such as soil erosion control. We designed indicators for assessing smallholder farmers' well-being by incorporating expert opinions for determining the weights of each well-being indicators using the questionnaire. Figure 2 shows the detailed links of the ES supply-demand relationships.

\subsection{Data Sources and Methods}

\subsubsection{Estimation of ES supply}

Estimating crop yield to determine the ES supply is always a challenging exercise that employs either a subjective or objective method. Subjective method of determining crop yield is carried out in farms owned by smallholder farmers and prefered to use this method because it is easy to implement [26]. Our study used subjective methods and focused on ecosystem goods and services considered more relevant to the study region. The selected ES supplies include cereal crops, fruits and coffee yields. They were chosen because they are easy to identify their supply, social demand and mismatches from cultivated and agroforestry land-use types (Table 2). The data for provisioning ES supplies were obtained from the head of smallholder farmer households in each Kebele ${ }^{1}$ in quintal ${ }^{2}$ using a semi-structured interview. Then, the total ES supply of each provisioning ES was collected from each smallholder farmers in the study region (Eq. 1).

\footnotetext{
${ }^{1}$ Kebeles are the smallest and lowest level of political administration units in Ethiopia.

2 a unit of weight. 1 quintal equal to 100 kilograms.
} 
$T Y_{\text {cereals,fruits \& coffee }}=($ Yield in quintals per year in each $\mathrm{HH})$

Where: TY is the total yield of cereals, fruits and coffee in quintal, HH: household

Our ES supply estimation also included regulation ecosystem service such as soil erosion control of the study region. Such regulating ecosystem service was estimated indirectly using the study region's annual soil loss. We assumed that the lesser yearly soil loss (t/ha) would have higher soil erosion control regulating ES supply in the study region. The annual soil loss of the study area was computed using the revised universal soil loss equation (RUSLE), adapted to Ethiopian conditions by Hurni [27] as described in Eq. (2).

$$
A_{r}=R * K * L S * C * P
$$

Where: $A_{r}$ is the annual soil loss in $t / h a ; R$ is the rainfall and runoff erosivity factor; $K$ refers the soil erodibility factor; LS is slope steepness and length factor; C is the cover management factor, and $\mathrm{P}$ is the conservation support practice factor.

\subsubsection{Estimation of ES social demand}

The subjective estimation method was employed to estimate ES social demand for smallholder farmers. The ES social demand for ES supply such as cereal crops, fruit and coffee, was obtained depending on the household consumption of these crops in quintals using the current market values. We assumed that the higher demand for these provisioning ES is driven by increased market values [15]. The social need for each ES supply was collected in quintals from each smallholder farmers' household head using a semi-structured interview. The total demand estimation was carried out by collecting ES social demand from each smallholder farmer household head in the study region (Eq. 3). 
$T D_{\text {cereals,fruits \& coffee }}=(\mathrm{HH}$ consumption in quintals per year $)$

Where: TD is the total demand of cereal crop, fruits and coffee in quintals, HH: household

To estimate the social demands for regulating ES such as soil erosion control, we used the benefit transfer method. Smallholder farmers' value attached to soil erosion control was taken as social demand for abating soil loss in the study region. We assumed that the higher annual soil loss ( $\mathrm{t} / \mathrm{ha}$ ) would indicate the more increased need for soil erosion control regulating ecosystem service supply in the study region. The estimation of social demands for soil erosion control ES was computed using the following formula (Eq. 4).

$E S V_{f}=\sum\left(A_{k} \times V C_{k f}\right)$

Where: $\mathrm{ESV}_{\mathrm{f}}=$ estimated ecosystem service values of function ' $\mathrm{f}$ ', $\mathrm{A}_{\mathrm{k}}=$ the area (ha) and $\mathrm{VC}_{\mathrm{kf}}=$ value coefficient of function ' $\mathrm{f}$ ' (US \$ ha-1 yrea-1 for each LULC class ' $\mathrm{K}$ '.

We obtained the datasets used for estimating social demands for soil erosion control (ecosystem service value coefficients) from Temesgen, WU [28]. We used a semi-structured interview and focus group discussion (FGD) for a detailed understanding of the social demands of soil erosion control in the study region.

\subsubsection{ES Supply-Demand Ratio (ESDR) analysis}

We calculated ES Supply-Demand Ratio (ESDR) analysis for cereal crops, fruit and coffee provisioning ESs. The ES supply-demand ratio tries to connect the ES supplies with social demands. Their mismatches can be easily identified using the supply-demand ratio analysis as described by Li, Jiang [29] under Eq. (5). 
$E S D R=\frac{\left(E S S_{\text {actual }}\right)-\left(E S D_{\text {human }}\right)}{\left(E S S_{\text {max }}+E S D_{\max }\right) / 2}\left\{\begin{array}{c}>0, \text { excess ESS } / \text { surplus } \\ =0, \text { balance } \\ <0, \text { excess } E S D / \text { deficit }\end{array}\right\}$

Where: ESS and ESD are the actual ES supply and ES demand for a specific ES, respectively. $\mathrm{ESS}_{\max }$ and ESD $\max$ indicate the maximum values of ES supply and demand. A positive value shows an ES surplus, zero suggests a balance between ES supply and demand, and a negative value shows a deficit of ES supply relative to demand [29, 30].

\subsubsection{Assessment of smallholder farmers' well-being}

For assessing smallholder farmers' well-being, we used a participatory approach focusing on well-being dimensions prepared by MEA [1], such as basic material for a good life, health, security and social relations. We established a set of 11 well-being indicators from the given domains to assess smallholder farmers' well-being (Table S2). Expert opinions made the selection and the weight of each indicator. To normalize the weight of each indicator, we employed the techniques of the analytical hierarchical process (AHP). Subjective satisfaction was applied to obtain the well-being level of each indicator and the well-being level of smallholder farmers. A five-point Likert scale was employed to evaluate the satisfaction degree of smallholder farmers based on each indicator (i.e., $0.2=$ strongly dissatisfied, $0.4=$ dissatisfied, $0.6=$ neutral, $0.8=$ satisfied, and $1=$ very satisfied). All responses were coded in order from the lowest score of 0.2 to the highest score of 1 . A higher score represented a higher level of smallholder farmers' well-being. The well-being levels in contrasting agro-ecological zones were quantified by the mean level of all respondents' satisfaction degree within the study region.

\subsubsection{Sampling, Data processing and analysis}

We used multi-stage sampling techniques for collecting data. First, we stratified the study area into two agro-ecological zones. Second, purposive sampling was employed to identify the 
representative kebele from humid and semi-arid AEZ. Accordingly, 63 kebeles were selected, out of which 41 kebeles were from humid while 22 were from the semi-arid AEZ. In the third stage, a simple random sampling technique was employed to select sampled households. Given the relative homogeneity of households in terms of the agro-ecological zone (AEZ), and the repetitiveness of the responses given, around 5-6 households were selected from each kebele for semi-structured interviews and focus group discussion (FGD). To this end, a total of 317 households were selected, out of which 110 (34.7\%) were from semi-arid AEZ, while 207 (65.3\%) were from humid AEZ. We prepared questionnaires for semi-structured interviews and FGD in English. Then, we translated into three major local languages: Gede'uffa and Sidamuffa for the humid AEZ and Afaan Oromo for the semi-arid AEZ. All the interviews were conducted by the authors of this article and agricultural office experts. The spatial variation of each provisioning ecosystem goods was mapped using Inverse Distance Weighted (IDW) interpolation of ArcMap version 10.3.1 platforms. Finally, we used Spearman's rank correlations to test the ES supply and demand correlation. Radar diagram was also used to link smallholder farmers' well-being in each agro-ecological zone.

\section{Results}

\subsection{Cereal crop and fruit production: Provisioning ES supplies and their spatial maps}

High supply of provisioning ecosystem goods such as cereal crops, fruits and coffee were observed in the humid agro-ecological zone (AEZ). 98.2\%, 86.7\% and 71.8\% of barley, wheat and teff supplies were respectively observed in the humid AEZ. Around $78.6 \%$ of cultivated land is located in the humid AEZ, and only $21.4 \%$ is in the semi-arid AEZ, so the supply of major crops was mainly from humid AEZ (Table S3). Similarly, high provisioning of fruit ES supply such as Avocado (93.5\%) and Mango (93.3\%) was observed in humid AEZ. High coffee 
production (90.1\%) was also observed in humid AEZ relative to semi-arid AEZ. Excess demand was found on cereal crop production, while excess ES supply was more evident on fruit and coffee production in humid AEZ. The higher mismatch was observed on teff crop followed by wheat and barley crops in humid AEZ. The spatial distribution of ES supplies both in humid and semi-arid AEZ was shown in Figure 3.

In semi-arid AEZ, all ES supplies were found low compared to humid AEZ and have shown excess demand (Table S4). The expansion of cultivated land has improved the supply of cereal crops but not exceed the social demand. As aresult, the mismatch ratio of all provisioning ES supplies in the region had shown a negative ratio (excess demand). The higher difference was seen on barley followed by wheat and teff. The spatial distribution of provisioning ecosystem goods of fruit and coffee is shown in Figure 4.

The result from the interview on ES supply showed that $78 \%$ and $40 \%$ of smallholder farmers inhabited in humid and semi-arid AEZs respectively believed that the study region provided an important provisioning ES to the community (Figure 5). Compared with other ecosystem services such as soil erosion control, smallholder farmers preferred provisioning ES, which was more attached to their well-being levels. Therefore, smallholder farmer prioritized provisioning services than regulating services in the study area. Figure 5 indicates that $97 \%$ of the smallholder farmers observed coffee crop as an important ecosystem good followed by barley (94\%), avocado (93\%), mango (91\%) and wheat (70\%) in humid AEZ. Similarly, 68\% of the respondents viewed barley as an important provisioning ecosystem goods, followed by wheat (44\%), coffee (39\%) and teff (45\%) in semi-arid AEZ. Only $29 \%$ and $27 \%$ of the respondent viewed avocado and mango fruit, respectively as an important provisioning ecosystem goods.

\subsection{Soil erosion rate: Regulation ES and its spatial distribution}


The rate of soil loss of the study region was spatially different across agro-ecological zones. The observed average soil loss varies from 100-500 t/ha/year for semi-arid to 100-800 t/ha/year for humid AEZ (Figure 6). High soil loss was concentrated in the humid AEZ, covering large areas of the region. Due to undulating topography and high rainfall coupled with expanding cultivated lands, humid AEZ experienced the higher soil loss compared to semi-arid AEZ. However, the presence of agroforestry land-use types has given the area strong soil retention and erosion control capacity. Therefore, soil erosion control ES supply was much higher as compared with semi-arid AEZ (Figure 7). In the semi-arid AEZ, the land is relatively flat with relatively denser trees/bushes/shrubs coverage, and low rainfall $(622-1,254 \mathrm{~mm})$ distribution, had experienced relatively low soil losses.

Regarding the social demand for controlling soil loss, $85 \%$ of smallholder farmers were viewed as more important in the humid AEZ, where soil erosion potential was high. In humid AEZ, ES supply of soil erosion control has shown a gradual decrease in the period between 1988 and 2018 (Figure 7) and estimated as $16.57,16.11$ and 15.1 million US \$ per year for the period of 1988, 2003 and 2018, respectively. As a result, the demand for controlling soil erosion has been increased in humid AEZ in the previous years (Figure 8).

Similarly, in semi-arid AEZ, more than $60 \%$ of smallholder farmers were viewed soil erosion control as important for their livelihood. The ES supply of soil erosion control has been gradually decreased and estimated to $4.63,3.56$ and 2.06 million US \$ per year for the period of 1988, 2003 and 2018, respectively (Figure 8). As a result, the social demand for soil erosion control has been increasing gradually since the recent decades.

\subsection{Assessing the mismatches between ES supply and social demand}


In our study area, the ES supply was not in accordance with the smallholder farmers' social demand. The result of spearman's rank shows positive correlation between ES supply and social demand both in humid (Rho $=0.84 ; \mathrm{p}<0.05$ ) and semi-arid (Rho $=0.76 ; \mathrm{p}<0.05$ ) agroecological zones (AEZ). However, the study area did not satisfy the alarmingly increasing demands of smallholder farmers for ES goods. The supply of cereal crops was less than the social demand, indicating excess deficits of cereal crops. In the study area, food production from cereal crops was viewed as an important ES supply for smallholder farmers' well-being, but its supply from the ecosystem was lower (Table S3 and Table S4). The ES supply for cereal crops in the humid AEZ was relatively higher compared with semi-arid AEZ, but not able to satisfy the demands of smallholder farmers. Excess supply of fruit products was observed in humid AEZ. However, its temporal distribution is not even and its excess supply remains only for a limited number of months (4-5). Contrary to humid AEZ, deficit of fruit products was observed in semiarid AEZ. Coffee is one of the strategic crops in the humid AEZ. Its supply remains only for a limited number of months (September to December). Within these limited months, coffee products remains excess in humid AEZ. However, in semi-arid AEZ, since the area is not suitable for coffee production, high mismatches (deficit) have been observed. The biophysical supply for soil erosion control has shown a gradual decrease in the study area. However, the social preference for soil erosion control was relatively high, showing the mismatch between ES supply and social demand in the region.

\subsection{Smallholder farmers' well-being}

Across the study area, the weight of well-being indicators and their subjective degree of satisfaction had spatial differences (Figure 9 A and B). Of all indicators, income had the highest weight in both humid and semi-arid AEZs (Figure 9), which was in accordance with the 
relatively low level of socio-economic development of the region. Across the study area, next to income, high weight was given to physical health and mental health relative to other well-being indicators. Concerning subjective satisfaction level of well-being, the relationship among neighbours (RAN) and relationships among family members (RAFM) had obtained the highest weight relative to others (Figure 9). However, their weights as well-being indicator were remained low compared with others. Moreover, the subjective satisfaction degree for physical health and mental health was relatively high. Their scores were found greater than 0.6 in both AEZs, which led smallholder farmers' judgment to "neutral" that neither satisfied nor dissatisfied level of well-being. In humid AEZ, well-being indicators such as water consumption, transportation and natural hazard had a relatively higher well-being satisfaction degree, with scores ranging from 0.4 (dissatisfied) to 0.6 (neutral) (Figure 9 A). Indicators such as income, housing, food consumption and public security had lower well-being satisfaction degree, and their scores were less than 0.4 , which denotes the unsatisfied demand level of smallholder farmers.

\subsection{The relationships between ES supply and smallholder farmers' well-being}

Our analysis indicated that local smallholder farmers were highly dependent on the local provisioning ES. The utilization of ES was spatially different in the study region. The radar diagram (Figure 10) showed the difference between ES supply and smallholder farmers' wellbeing in the two agro-ecological zones. Relatively high smallholder farmers' well-being improvement was linked with a high supply of provisioning ecosystem services. For instance, both smallholder farmers' subjective well-being and the supply of provisioning ecosystem services were highest in the humid AEZ and lowest in the semi-arid AEZ. The Spearman's rank correlation showed that the smallholder farmers well-being has a positive correlation with the 
supply of provisioning ES both in humid $($ Rho $=0.8 ; \mathrm{p}=0.02)$ and semi-arid $($ Rho $=0.6 ; \mathrm{p}=$ 0.04) AEZs. The production of cereal crop, fruit and coffee was high in humid AEZ but lowest in semi-arid AEZ, which determined the income level of each smallholder farmers. The regulation ES such as soil erosion control was higher in humid but lowest in semi-arid AEZ, and these had a strong relationship with the local provisioning ESs and affects the well-being levels of smallholder farmers. Based on these ES spatial variations across the humid and semi-arid AEZs, smallholder farmers well-being had a strong spatial correspondence with the supplydemand mismatches in the provisioning ES. Compared with humid AEZ, the semi-arid AEZ had relatively serious mismatches in provisioning services (Table S4), and correspondingly, the smallholder farmers' well-being in the region was low compared with humid AEZ.

\section{Discussion}

\subsection{Ecosystem services supply, social demand and their mismatches}

Ecosystems are natural capitals that strongly link human being with nature through providing ecosystem supplies to satisfy social demands [31]. They linked together either through synergy or in a trade-off manner. Land use is the platform that links ES supply and social demands in a given area [12]. ES supply ensures the continuous flow of myriads of ecosystem services [32], while ES social demand is related to the social beneficiaries [32-34]. However, mismanagement of land-use [35-37] and other factors such as population pressure have inevitably altered the structure as well as service delivery capacity of ecosystems at a different scale. As different scholars have witnessed [For instance; 9, 12, 38], LULC change can alter the normal flow of ES supply and social demand and made the relationship more complex. This complexity has made difficult to understand and become a challenge in optimizing sustainability, demanding more research to clarify these relationships $[2,9]$. 
Smallholder farmers' well-being is affected by positive or negative relationships between ES supply and social demands. The negative relationships can be reconciled by application of sustainable land use management, which is required to minimize mismatch. Different frameworks have been proposed by different scholars that incorporate ES supply-side and demand-side such as ES and benefits framework, the ES delivery chain and a framework for assessing ES supply and social demand [39-41]. Moreover, indicators such as the supply-demand ratio and market approach were applied to find mismatches between ES supply and social demands [9, 15]. The framework (Figure 3) that we proposed has linked ES supply, social demand and smallholder farmers' well-being by incorporating different approaches such as biophysical indicators, market approach and statistical analysis.

Our result indicated that ES supplies were not found in accordance with the existing ES social demand in the study region. The imbalance has created ES supply-demand mismatches. Different factors are believed to be involved in disrupting the balance between ES supply and demand. Considering the ES supply side, the weak performance of ecosystem function could cause the mismatches [15]. For instance, in humid AEZ due to the high amount of rainfall, soil acidity was the main problem that inhibits crop yields, becoming the main factor in causing crop yield deficit and supply-demand mismatches. Another example is, due to frequent ploughing and application of low soil input, the fertility of the soil in the humid AEZ was poor, and the size of cultivated land was also limited, which become the main cause for low yield of wheat, barley and teff crops. In these areas, a shortage of cultivated land is the main limiting factor for increased crop yields [28, 42, 43]. On the other hand, the dominant land-use types of humid AEZ is agroforestry, which could not have sufficient place for cereal crop production, had played its 
role in promoting mismatches between ES supply and demand in cereal crops. Similarly, in semi-arid AEZ, ES supply of cereal crop products was limited due to less amount of rainfall distribution, which become the main cause of mismatches in the region. Different studies have reached on similar results [43-46] indicating the minimum production of cereal crops in the study region.

On the demand side, the higher society preference for ES supplies (wheat, barley and teff) could also cause mismatches between ES supply and social demand. The higher demand for ES supply may be related to increased population, land-use change or economic development. For instance, in the past three decades, human population of the study region was increased by $124.6 \%$ (humid AEZ) and $125.7 \%$ (semi-arid), causing a huge impact on the expansion of cultivated land and reduction of vegetation resource (Figure 11). The increased population could be partially explained by the custom of polygamy and community resistance to family planning efforts made by the government $[37,42,43,46-49]$. The continuous growth in the economic development of the country (Ethiopia) has increased the purchasing power of smallholder farmers, to some extent [50]. Given the limited ES supplies of cereal crops, the increased purchasing power has contributed to higher demand to be surfaced in the region. In response to increased social demand for cereal crops, increased number of agricultural investors (both private and government) have been seen especially in the semi-arid AEZ, which is the main driver of landuse change of the area. The proclamation of the "agricultural Development-Led Industrialization $(A D L I)$ " policy framework has further aggravated woodland and forestland conversion to cultivated land. This policy framwork has put other ES supplies under high pressure, which further aggravate the demand of the society for provisioning ES of the region [51]. 
In contrast to ES supply of cereal crop products, ES supply of fruit and coffee were higher than social demands in humid AEZ. The supply of these goods surpasses the demand, indicating the relatively excess production in the area [44, 47], although it has uneven distribution throughout the year. In the humid AEZ, coffee was the primary source of cash, and the major part of the area has been covered by coffee $[52,53]$. Since coffee is an international commodity and it is a major source of foreign currency, its production has been increasing over time. Much of the increase in coffee production in the current years has been due to an increase in cultivated area and attention given by the government. However, to what extent expansion of land for coffee production can continue remains a question. Hence, obtaining higher yield rates of coffee and other cereal crops remains a challenge of Ethiopia's agricultural system and no exceptions for other East African countries. However, such excess supply remained only for three to four months and the rest months had very limited/no production. This was happened due to less use of irrigation technology during the dry season. In addition to coffee production, fruit production (mango and avocado) was considered as supplementary product next to coffee in the humid AEZ. Such fruit produced predominantly in the agroforestry land-use mostly for own consumption and markets. The suitability of the climatic variables resulted in relatively stronger ES functions for the production of coffee and fruit trees in the area. However, in semi-arid AEZ, due to unsuitable climatic conditions for coffee and fruit production, supplies of these crops were very low that does not satisfy the social demands. To fill the gaps, much of these cereal crops have been purchased from other nearby areas where excess supply is available [46].

\subsection{Linking ES supplies with smallholder farmers' well-being}

The analysis of our result indicated that smallholder farmers' well-being had a positive correlation with provisioning ES supply (cereal crops, fruit and coffee) and a negative correlation 
with regulation services such as soil erosion rate. Different studies have shown similar results [1, 12, 15, 20, 22, 32]. Moreover, as reported by [1], provisioning ES such as food production and human well-being have shown improvements. This was happened because human well-being is highly dependent on provisioning ecosystem services [1]. In contrast, the supply of most regulating services such as soil erosion control has been declined due to the expansion of cultivated land and the subsequent increases in deforestation. For instance, the observed mismatch on cereal crops in humid and semi-arid AEZs could directly influence smallholder farmers' well-being through food variation. On the other hand, due to less production of cereal crops (wheat, barley and teff), smallholder farmers of the region have been paying for those services in the markets. Thus, the mismatch could have an impact on the smallholder farmers' income, which is an essential indicator of smallholder farmers' well-being in the region. During our focus group discussion (FGD), smallholder farmers revealed that the mismatches between regulating ES supply and demand have a relatively had low impact on their well-being compared with mismatches of provisioning ES supply and demand.

Both in humid and semi-arid AEZ, the smallholder farmers preference was higher for provisioning ES than regulating ES. However, it is impossible to neglect the maintenance role of regulating ES, because they underpin the production of provisioning ES [9], but in the long run have an impact of smallholder farmers' well-being $[1,9,12]$. Comparing agro-ecological zones, the regulating ES of humid AEZ was higher than semi-arid AEZ and smallholder farmers' wellbeing too. This was due to the presence of agroforestry land-use type, which enables the continuous supply of another provisioning ES such as water, raw materials and root and tubers. Moreover, the indigenous knowledge that has been deep-rooted in the society has made the 
inhabitants to have higher ecological predispositions and awareness, so they view regulating ES as more important for their life [47].

The weight of well-being indicators given by smallholder farmers was spatially varied across the study area. In humid AEZ, higher weight of well-being indicators was obtained relative to semi-arid AEZ. Smallholder farmers who live in humid AEZ practice sedentary agriculture. They also live near to urban areas, and this has made the region to have advantage of location for experiencing urban life and helped them to improve their living condition. Agroforestry land-use type has contributed in providing raw material inputs for making house, food (fruits and root and tubers) and improves water availability. Housing was considered as an essential item indicating the level of wealth smallholder farmers had in the local area. Smallholder farmers who have a house with corrugated iron sheet roof recognized by most people as they have better living conditions than smallholder farmers with grass roofs. However, in semi-arid AEZ, the weight of these well-being indicators was lower (except for income) than humid AEZ. For instance, farmers living in semi-arid AEZ mostly follow pastoralist living condition. Pastoralist community mostly have mobile houses made of wood, grasses and plastic sheets.

\subsection{Policy implications for sustainable ES and smallholder farmers' well-being}

Ecosystem services are essential components of smallholder farmers' well-being [15, 54]. It is essential to identify the link among ES supply, social demand and smallholder farmers' wellbeing along with the changing LULC types, not only for the sake of scientific research but also for informing policymakers. Acknowledging ES supply and social demand to gain the attention of policymakers and other stakeholders is important. Such demonstration must be considered in environmental and biodiversity policies that underpin sustainable management of ecosystems. Avoiding the supply-demand relationships from policy issues limits the integration of ES supply 
and social demands into the policy-making processes $[9,55]$. The supply-demand mismatch gap should be balanced or at least should be narrowed by policy instruments up to the stage that should not negatively affect the well-beings levels of smallholder farmers. This is because policy and land use planning decisions largely influence the way land is managed [56].

Our ES assessment result can provide essential information to assist land users, policymakers or other practitioners to maintain ES and improve smallholder farmers' well-being. The policy instruments that prohibit ES degradation are essential, especially for the poor people who most directly depend on ecosystem services [55]. Up-to-date provisioning of information on the state and trend of ES help practitioners to devise relevant conservation strategies/policies to reduce ES degradation $[12,54,55]$. For instance, pressure from ever-increasing human activities has been imposing a massive impact on multiple ESs in the study region. These pressures on ESs are the result of unplanned land use and lack of integrated planning approach. For instance, for the sake of increasing cereal crop production in humid AEZ, a large area of forestland, wetland, grassland and woodland were converted to cultivated land without planning. The increased cereal crop production due to cultivated land expansion may persuade people to consider as an economically profitable practice. But, the cost incurred due to multiple ES loss may not be covered by economic gains of increased cereal crop production. Therefore, a policy option for intensifying cereal crop production should be highly relevant in the study area.

Besides, soil conservation and watershed management policies should continue to be implemented. Banning hillside ploughing, protecting wetlands from sediment siltation, irrigation water management in the semi-arid AEZ and cultivated land intensification should be supported with appropriate policy options. Policies that intervene at any part of the human-ES interaction are important. 


\section{Conclusion}

Our result indicated that the provisioning ES supply of the study area was not completely in accordance with the social demands for ES. ES supply-demand mismatches were observed both in humid and semi-arid AEZs. The source of the mismatch was emanated either from supply-side or from demand-side. The deficit of cereal crops was observed both in humid and semi-arid AEZs of the study region. The deficit was probably caused by increased demand due to the large population and less productivity. Excess supply of provisioning ES such as fruit products and coffee was observed in humid AEZ, but this excess supply remains only for limited months. In contrast, the deficit of fruit and coffee products was seen in semi-arid AEZ due to less production and unfavourable climatic condition of the region. Regulating ES supply such as soil erosion control was higher in humid AEZ due to the presence of agroforestry land-use type. But the risk of soil erosion was high due to the existing undulating topography and torrential rainfall, and hence, the social demand for soil erosion conservation was high in the area. The mismatches between provisioning ES supply and demand had a strong impact on smallholder farmers' wellbeing. The Spearman's rank correlation showed that the smallholder farmers well-being has a positive correlation with provisioning ES supply in the study region.

Smallholder farmers' well-being indicators and their level of well-being satisfaction were spatially varied between agro-ecological zones. Income has received the highest weight as an indicator for smallholder farmers' well-being both in humid and semi-arid AEZs. The subjective satisfaction level of smallholder farmers for relations among neighbour and family members was higher both in humid and semi-arid AEZs. Managing regulating ES such as soil erosion control improves the provisioning ES supplies and helps to satisfy society demands. Unfortunately, 
many, if not most smallholder farmers consider these regulating ES supplies as of free and valueless with no economic values. Smallholder farmers may not pay directly for the decline of regulating ES supplies but pay for their loss and impacts on provisioning ES supplies and wellbeing. Therefore, we suggest policies like controlling population growth, applying intensive cereal crop production and strengthening integrated watershed management in the study region.

\section{Abbreviations}

LULC: Land use land cover; ES: Ecosystem service; ED: Ecosystem disservice; ESV: Ecosystem service valuation; AEZ: Agro-ecological zone; FGD: Focus group discussion; ADLI: Agricultural Development-Led Industrialization; RAN: Relationships among neighbors; RAFM: Relationships among family members; INC: Income; HO: Housing; FC: Food consumption; WC: Water consumption; TR: Transportation; PH: Physical health; MH: Mental health; PS: Public security and NH: Natural Hazard.

\section{Declarations:}

\section{Acknowledgements}

We are grateful for the willingness and support of local farmers and government officials who allowed us to carry out interview and group discussion. We thank also Dilla University for logistic arrangement. The authors are indebted to thank the National Natural Science Foundation of China and International Cooperation and Cultivation Project of Nanjing Agricultural University for financial support in conducting this study.

\section{Authors' contributions}


HK designed the study and undertook all practical elements of the study, including setting up sample, analyzing results, producing tables and figures and writing the manuscript. WW, AL, ZW, TE, WN, AA and AAM contributed ideas for the overall flow of the manuscript, sections needs to be included and helps to analyze the result and contributed for the discussion. All authors have read, comment and approved the final manuscript.

\section{Funding}

The first author of this manuscript (HK) was supported by grants from the National Natural Science Foundation of China (41571176) and International Cooperation and Cultivation Project of Nanjing Agricultural University (Fund No. X201915).

\section{Availability of data and materials}

All data generated or analyzed during this study are included in this manuscript under supplementary information files.

\section{Ethics approval and consent to participate}

Not applicable.

\section{Consent for publication}

Not applicable.

\section{Competing interests}

The authors declare that they have no competing interests

\section{Reference}


1. Millennium Ecosystem Assessment (MEA): Ecosystems and Human Well-being: Synthesis. Island Press, Washington, DC. 2005.

2. Castro AJ, Verburg PH, Martín-López B, Garcia-Llorente M, Cabello J, Vaughn CC, López E: Ecosystem service trade-offs from supply to social demand: A landscape-scale spatial analysis. Landscape Urban Plan 2014, 102-110, https://doi.org/10.1016/j.landurbplan.2014.08.009.

3. Summers JK, Smith LM, Fulford RS, De Jesus Crespo R: The Role of Ecosystem Services in Community Well-Being. Ecosystem Services and Global Ecology 2018, 145: 13, 10.5772/intechopen.74068.

4. Arowolo AO, Deng X, Olatunji OA, Obayelu AE: Assessing changes in the value of ecosystem services in response to land-use/land-cover dynamics in Nigeria. Sci Total Environ 2018, 636: 597-609, https://doi.org/10.1016/j.scitotenv.2018.04.277.

5. Barrett $\mathrm{CB}$, Travis AJ, Dasgupta P: On biodiversity conservation and poverty traps. Proceedings of the National Academy of Sciences 2011, 108(34): 13907-13912, https://doi.org/10.1073/pnas.1011521108.

6. Fisher JA, Patenaude G, Meir P, Nightingale AJ, Rounsevell MD, Williams M, Woodhouse IH: Strengthening conceptual foundations: analysing frameworks for ecosystem services and poverty alleviation research. Glob Environ Change 2013, 23(5): 1098-1111, https://doi.org/10.1016/j.gloenvcha.2013.04.002.

7. Sandhu H, Sandhu S: Linking ecosystem services with the constituents of human well-being for poverty alleviation in eastern Himalayas. Ecol. Econ. 2014, 107: 65-75, https://doi.org/10.1016/j.ecolecon.2014.08.005. 
8. Adams WM, Aveling R, Brockington D, Dickson B, Elliott J, Hutton J, Roe D, Vira B, Wolmer W: Biodiversity conservation and the eradication of poverty. science 2004, 306 (5699): 1146-1149, DOI: 10.1126/science.1097920.

9. Wei H, Liu H, Xu Z, Ren J, Lu N, Fan W, Zhang P, Dong X: Linking ecosystem services supply, social demand and human well-being in a typical mountain-oasis-desert area, Xinjiang, China. Ecosystem Services 2018, 31: 44-57, https://doi.org/10.1016/j.ecoser.2018.03.012.

10. Zhang Z, Gao J, Gao Y: The influences of land use changes on the value of ecosystem services in Chaohu Lake Basin, China. Environ. Earth Sci. 2015, 74(1): 385-395, https://doi.org/10.1007/s12665-015-4045-z.

11. Tolessa T, Senbeta F, Abebe T: Land use/land cover analysis and ecosystem services valuation in the central highlands of Ethiopia. Forests, Trees and Livelihoods 2017, 26(2): 111-123, https://doi.org/10.1080/14728028.2016.1221780.

12. Wang X, Dong X, Liu H, Wei H, Fan W, Lu N, Xu Z, Ren J, Xing K: Linking land use change, ecosystem services and human well-being: A case study of the Manas River Basin of Xinjiang, China. Ecosystem Services 2017, 27: 113-123, 10.1016/j.ecoser.2017.08.013.

13. Leviston Z, Walker I, Green M, Price J: Linkages between ecosystem services and human wellbeing: A Nexus Webs approach. Ecol. Indic 2018, 93: 658-668, https://doi.org/10.1016/j.ecolind.2018.05.052.

14. Lin X, Xu M, Cao C, P Singh R, Chen W, Ju H: Land-Use/Land-Cover Changes and Their Influence on the Ecosystem in Chengdu City, China during the Period of 1992-2018. Sustainability 2018, 10(10): 3580, https://doi.org/10.3390/su10103580. 
15. Lorilla RS, Kalogirou S, Poirazidis K, Kefalas G: Identifying spatial mismatches between the supply and demand of ecosystem services to achieve a sustainable management regime in the Ionian Islands (Western Greece). Land Use Policy 2019, 88: 104171, https://doi.org/10.1016/j.landusepol.2019.104171.

16. Costanza R, d'Arge R, de Groot R, Farber S, Grasso M, Hannon B, Limburg K, Naeem S, O'neill RV, Paruelo J: The value of the world's ecosystem services and natural capital. nature 1997, 387: 253-260, https://doi.org/10.1038/387253a0.

17. Braat LC, De Groot R: The ecosystem services agenda: bridging the worlds of natural science and economics, conservation and development, and public and private policy. Ecosystem services 2012, 1(1): 4-15, https://doi.org/10.1016/j.ecoser.2012.07.011.

18. Costanza R, De Groot R, Sutton P, Van Der Ploeg S, Anderson SJ, Kubiszewski I, Farber S, Turner RK: Changes in the global value of ecosystem services. Glob Environ Change 2014, 26: 152-158, https://doi.org/10.1016/j.gloenvcha.2014.04.002.

19. Kindu M, Schneider T, Teketay D, Knoke T: Changes of ecosystem service values in response to land use/land cover dynamics in Munessa-Shashemene landscape of the Ethiopian highlands. Sci Total Environ 2016, 547: 137-147, https://doi.org/10.1016/j.scitotenv.2015.12.127.

20. Wei H, Fan W, Wang X, Lu N, Dong X, Zhao Y, Ya X, Zhao Y: Integrating supply and social demand in ecosystem services assessment: A review. Ecosystem services 2017, 25: $15-27$.

21. Haines-Young R, Potschin M: The links between biodiversity, ecosystem services and human well-being. In: Raffaelli D and Frid C (eds): Ecosystem Ecology: a new synthesis, 
BES Ecological Reviews Series, Cambridge University Press 2010, 1: 110-139, DOI: $10.1017 /$ СBO9780511750458.007.

22. Mehring M, Ott E, Hummel D: Ecosystem services supply and demand assessment: Why social-ecological dynamics matter. Ecosyst. Serv 2018, 30: 124-125, https://doi.org/10.1016/j.ecoser.2018.02.009.

23. Fabricius C, Ainslie A, Cloete J, Shackleton C, Shackleton S, Urquhart P, Gambiza J, Nel E, Rowntree K, Mortimore M: Situation Analysis of Ecosystem Services and Poverty Alleviation in arid and semi-arid Africa. Consortium for Ecosystem Services for Poverty $\begin{array}{llll}\text { Alleviation } & \text { (ESPA) } & \text { Online }\end{array}$ https://www.espa.ac.uk/files/espa/Final\%20Report\%20Africa.pdf/accessed February, 2021.

24. Gashaw T, Tulu T, Argaw M, Worqlul AW, Tolessa T, Kindu M: Estimating the impacts of land use/land cover changes on Ecosystem Service Values: The case of the Andassa watershed in the Upper Blue Nile basin of Ethiopia. Ecosystem Services 2018, 31: 219-228, https://doi.org/10.1016/j.ecoser.2018.05.001.

25. Negussie W, Wu W, Alemayehu A, Yirsaw E: Assessing dynamics in the value of ecosystem services in response to land cover/land use changes in Ethiopia, East African Rift System. Appl. Ecol. Env. Res. 2019, 17(3): 7147-7173, http://dx.doi.org/10.15666/aeer/1703_71477173.

26. Food and Agriculture Organization (FAO): Methodology for Estimation of Crop Area and Crop Yield under Mixed and Continuous Cropping 2017, Online at http://www.fao.org/3/ca6514en/ca6514en.pdf/accessed February 2021. 
27. Hurni H: An ecosystem approach to soil conservation. In: El-Swaify, Samir A, Moldenhauer WC (Eds) Soil Erosion and Conservation, Ankeny, USA: Soil Conservation Society of America 1985, 73: 759-771, 10.7892/boris.77545.

28. Temesgen H, Wu W, Eshetu Y, Belewu B, Mengistie K: Variation in Ecosystem Service Values in an Agroforestry Dominated Landscape in Ethiopia: Implications for Land Use and Conservation Policy. Sustainability 2018, 10(4): 1126, doi:10.3390/su10041126.

29. Li J, Jiang H, Bai Y, Alatalo JM, Li X, Jiang H, Liu G, Xu J: Indicators for spatial-temporal comparisons of ecosystem service status between regions: A case study of the Taihu River Basin, China. Ecol. Indic 2016, 60: 1008-1016, https://doi.org/10.1016/j.ecolind.2015.09.002.

30. Chen F, Li L, Niu J, Lin A, Chen S, Hao L: Evaluating Ecosystem Services Supply and Demand Dynamics and Ecological Zoning Management in Wuhan, China. Int. J. Environ. Res. Public Health 2019, 16(13): 2332, https://doi.org/10.3390/ijerph16132332.

31. Santos-Martín F, Martín-López B, Garcia-Llorente M, Aguado M, Benayas J, Montes C: Unraveling the relationships between ecosystems and human wellbeing in Spain. PloS one 2013, 8(9): e73249, https://doi.org/10.1371/journal.pone.0073249.

32. Junyu C, Jiang B, Bai Y, Xu X, Alatalo JM: Quantifying ecosystem services supply and demand shortfalls and mismatches for management optimisation. Sci Total Environ 2019, 650: 1426-1439, https://doi.org/10.1016/j.scitotenv.2018.09.126.

33. Baró F, Haase D, Gómez-Baggethun E, Frantzeskaki N: Mismatches between ecosystem services supply and demand in urban areas: A quantitative assessment in five European cities. Ecol. Indic 2015, 55: 146-158, doi:10.1016/j.ecolind.2015.03.013. 
34. Yahdjian L, Sala OE, Havstad KM: Rangeland ecosystem services: shifting focus from supply to reconciling supply and demand. Front. Ecol. Environ. 2015, 13(1): 44-51, https://doi.org/10.1890/140156.

35. Berihun ML, Tsunekawa A, Haregeweyn N, Meshesha DT, Adgo E, Tsubo M, Masunaga T, Fenta AA, Sultan D, Yibeltal M: Exploring land use/land cover changes, drivers and their implications in contrasting agro-ecological environments of Ethiopia. Land Use Policy 2019, 87: 104052, https://doi.org/10.1016/j.landusepol.2019.104052.

36. Betru T, Tolera M, Sahle K, Kassa H: Trends and drivers of land use/land cover change in Western Ethiopia. Appl. Geogr. 2019, 104: 83-93, https://doi.org/10.1016/j.apgeog.2019.02.007.

37. Degife A, Worku H, Gizaw S, Legesse A: Land use land cover dynamics, its drivers and environmental implications in Lake Hawassa Watershed of Ethiopia. Remote Sensing Applications: Society and Environment 2019, 14: 178-190, https://doi.org/10.1016/j.rsase.2019.03.005.

38. Jones SK, Boundaogo M, Declerck FA, Estrada-Carmona N, Mirumachi N, Mulligan M: Insights into the importance of ecosystem services to human well-being in reservoir landscapes. Ecosyst. Serv 2019, 39: 100987, https://doi.org/10.1016/j.ecoser.2019.100987.

39. Bastian O, Syrbe R-U, Rosenberg M, Rahe D, Grunewald K: The five pillar EPPS framework for quantifying, mapping and managing ecosystem services. Ecosystem Services 2013, 4: 15-24, https://doi.org/10.1016/j.ecoser.2013.04.003.

40. Villamagna AM, Angermeier PL, Bennett EM: Capacity, pressure, demand, and flow: a conceptual framework for analyzing ecosystem service provision and delivery. Ecological Complexity 2013, 15: 114-121, https://doi.org/10.1016/j.ecocom.2013.07.004. 
41. Maimaiti A, Rusuli Y, He H, Audukerimu B: Spatio-temporal characteristics of vegetation water use efficiency and its relationship with climate factors in Tianshan Mountains in Xinjiang from 2000 to 2017. Chin J Plant Ecol 2019,43(6): 490-500, DOI: $10.17521 /$ cjpe.2019.0006.

42. Legesse A: The dynamics of Indigenous Knowledge Pertaining to Agroforestry Systems of Gedeo: implications to sustainability, PhD Dissertation, UNISA, South Africa 2013, accessed on http://hdl.handle.net/10500/14617.

43. Ketema H, Wei W, Legesse A, Wolde Z, Temesgen H, Yimer F, Mamo A: Quantifying smallholder farmers' managed land use/land cover dynamics and its drivers in contrasting agro-ecological zones of the East African Rift. GECCO 2020, 21: e00898, https://doi.org/10.1016/j.gecco.2019.e00898.

44. Regassa DA, Legesse A, Milstein T, Orkaydo OO: "Tree is life": The rising of Dualism and the Declining of Mutualism among the gedeo of southern ethiopia. Frontiers in Communication 2017, 2: 7, https://doi.org/10.3389/fcomm.2017.00007.

45. Ketema $\mathrm{H}, \mathrm{Wu} \mathrm{W}$, Temesgen $\mathrm{H}$ : Quantifying the ecological values of land use types via criteria-based farmers' assessment and empirically analyzed soil properties in Southern Ethiopia. Appl. Ecol. Env. Res. 2018, 16(6): 7713-7739, 10.15666/aeer/1606_77137739.

46. Temesgen $\mathrm{H}, \mathrm{Wu} \mathrm{W}$, Legesse A, Yirsaw E, Bekele B: Landscape-based upstreamdownstream prevalence of land-use/cover change drivers in Southeastern Rift escarpment of Ethiopia. Environ. Monit. Assess. 2018, 190(3): 166, 10.1007/s10661-018-6479-8.

47. Legesse A, Teferi B, Baudouin A: Indigenous agroforestry knowledge transmission and young people's participation in agroforestry practices: The case of Wonago Woreda, Gedeo Zone, Southern Ethiopia. Acta Geographica-Trondheim Serie A 2013. 
48. Kindu M, Schneider T, Teketay D, Knoke T: Drivers of land use/land cover changes in Munessa-Shashemene landscape of the South-central highlands of Ethiopia. Environ Monit Assess 2015, 187(7): 452, https://doi.org/10.1007/s10661-015-4671-7.

49. Sahle M, Yeshitela K: Dynamics of land use land cover and their drivers study for management of ecosystems in the socio-ecological landscape of Gurage Mountains, Ethiopia. Remote Sensing Applications: Society and Environment 2018, 12: 48-56, https://doi.org/10.1016/j.rsase.2018.09.002.

50. Moller LC: Ethiopia's great run: the growth acceleration and how to pace it. Washington, DC 2016.

51. Ketema H, Wei W, Legesse A, Wolde Z, Temesgen H, Yimer F, Mamo A: Quantifying smallholder farmers' managed land use/land cover dynamics and its drivers in contrasting agro-ecological zones of the East African Rift. Global Ecology and Conservation 2020, 21: e00898, https://doi.org/10.1016/j.gecco.2019.e00898.

52. Wolde Z, Tefera A, Yared S, Gezahagn T, Tadesse T: A review on coffee farming, production potential and constraints in Gedeo Zone, Southern Ethiopia. Journal of Natural Sciences Research 2017, 7(23): 1-9. ISSN 2224-3186 (Paper) ISSN 2225-0921 (Online).

53. Tadesse T, Tesfaye B, Abera G: Coffee production constraints and opportunities at major growing districts of southern Ethiopia. Cogent Food \& Agriculture 2020, 6(1): 1741982, https://doi.org/10.1080/23311932.2020.1741982.

54. Xu Z, Wei H, Fan W, Wang X, Zhang P, Ren J, Lu N, Gao Z, Dong X, Kong W: Relationships between ecosystem services and human well-being changes based on carbon flow-A case study of the Manas River Basin, Xinjiang, China. Ecosystem Services 2019, 37: 100934, https://doi.org/10.1016/j.ecoser.2019.100934. 
55. Geijzendorffer IR, Cohen-Shacham E, Cord AF, Cramer W, Guerra C, Martín-López B: Ecosystem services in global sustainability policies. Environ Sci Policy 2017, 74: 40-48, https://doi.org/10.1016/j.envsci.2017.04.017.

56. Maring L, Blauw M: Asset management to support urban land and subsurface management. Sci. Total Environ. 2018, 615: 390-397, https://doi.org/10.1016/j.scitotenv.2017.09.109. 


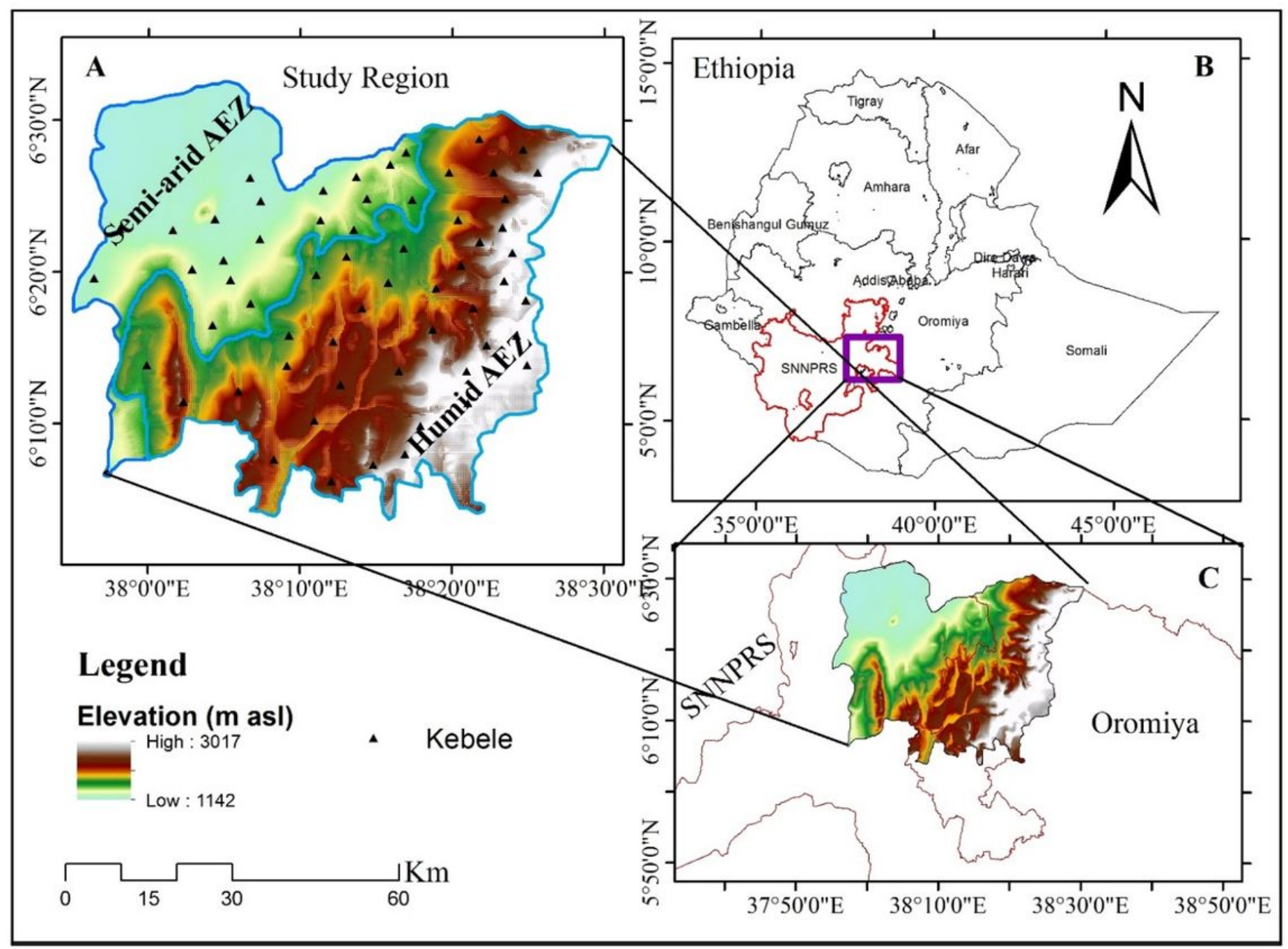

Figure 1

Map of the study region. A: Study area map, B: Map of Ethiopia, C: Neighborhood of the study area. Note: The designations employed and the presentation of the material on this map do not imply the expression of any opinion whatsoever on the part of Research Square concerning the legal status of any country, territory, city or area or of its authorities, or concerning the delimitation of its frontiers or boundaries. This map has been provided by the authors. 


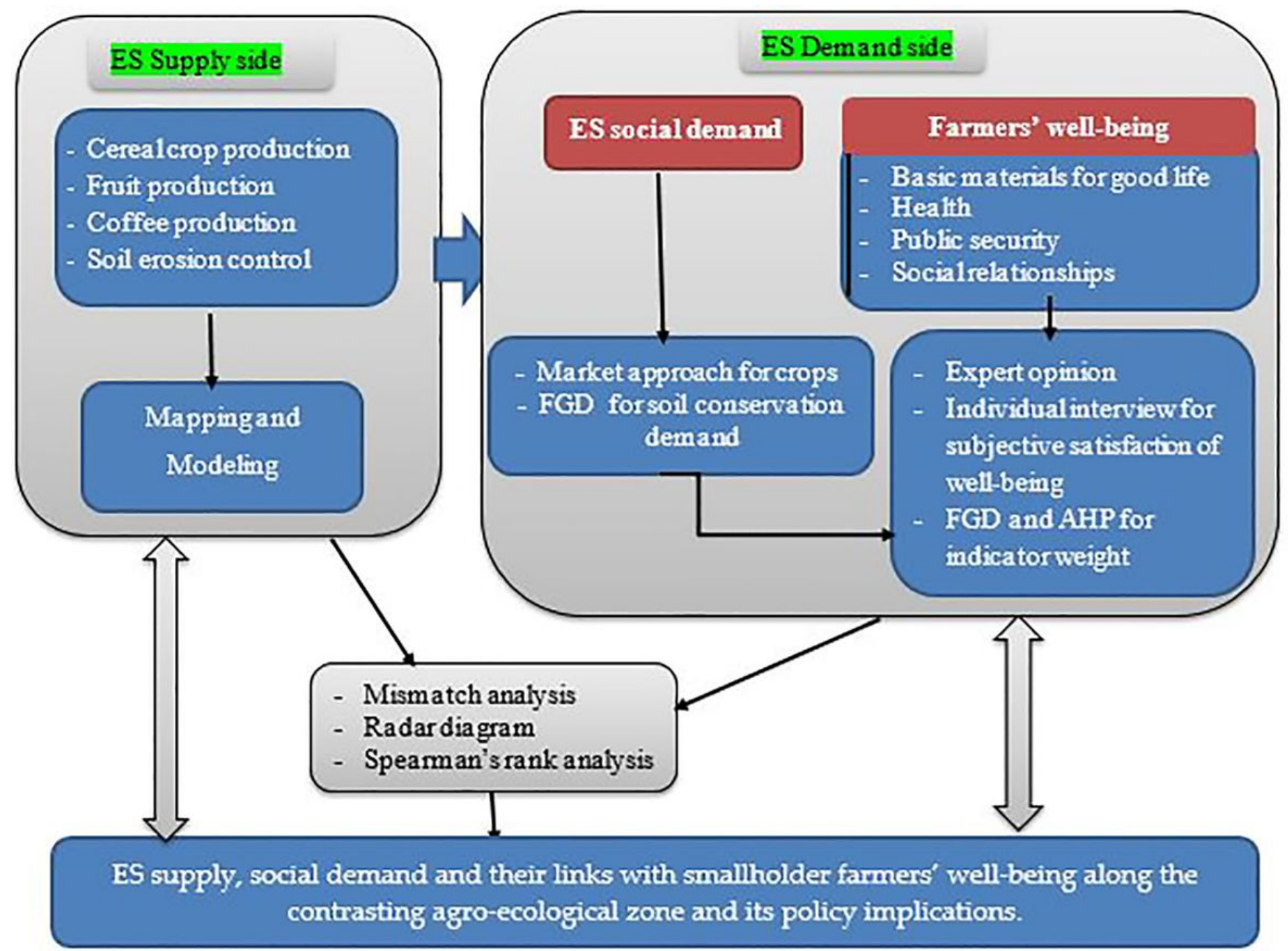

Figure 2

The framework to link ES supply, social demand and smallholder farmers' wellbeing in contrasting agroecological zone of the study region. (Adapted from Wei [9] 

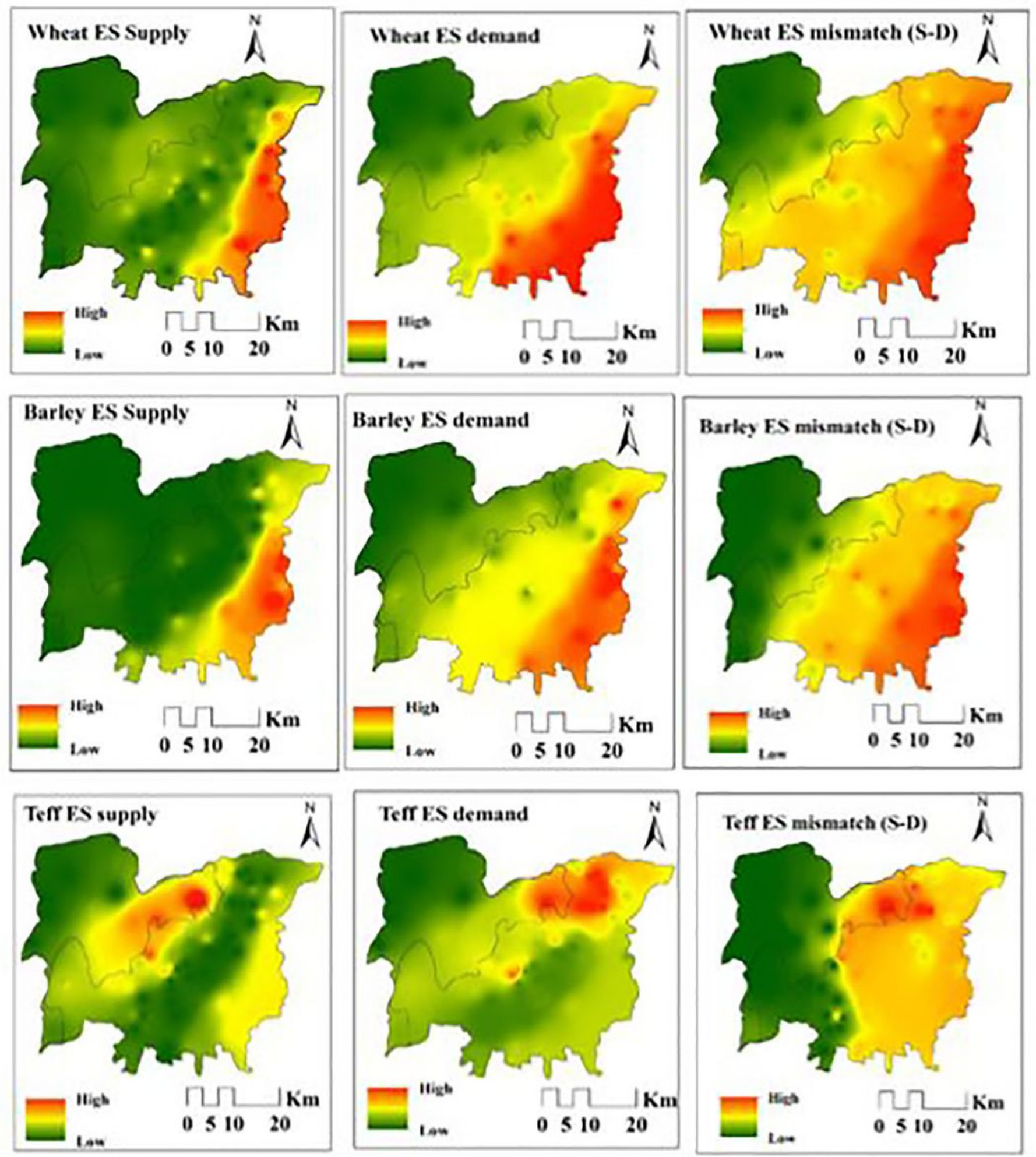

\section{Figure 3}

Spatial distribution of provisioning goods supply, social demands and their mismatches in humid and semi-arid agro-ecological zones (AEZ). Note: The designations employed and the presentation of the material on this map do not imply the expression of any opinion whatsoever on the part of Research Square concerning the legal status of any country, territory, city or area or of its authorities, or concerning the delimitation of its frontiers or boundaries. This map has been provided by the authors. 

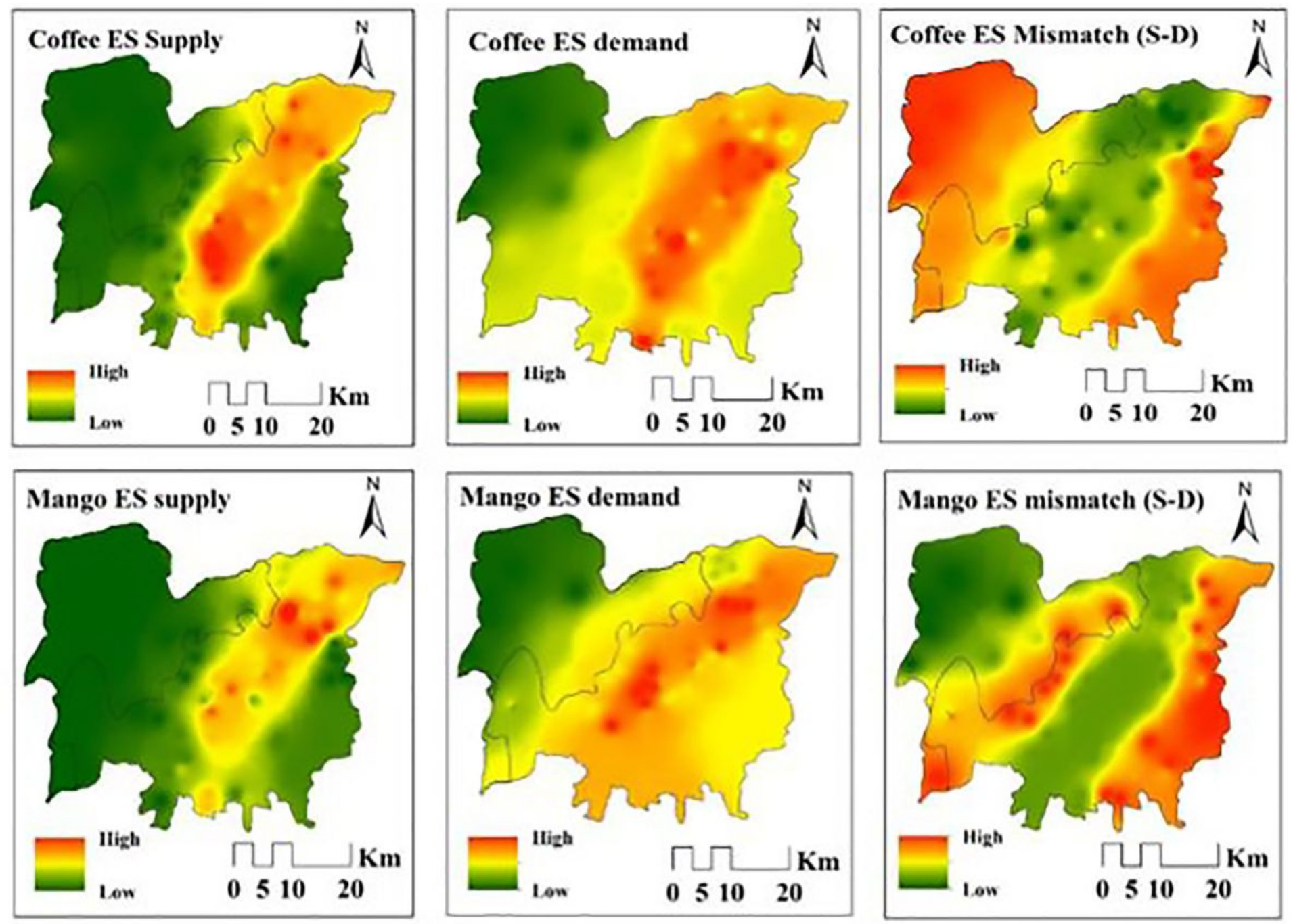

\section{Figure 4}

The spatial distribution of ES supply, demand and their mismatches of coffee, mango and avocado in humid and semi-arid agro-ecological zones (AEZ). Note: The designations employed and the presentation of the material on this map do not imply the expression of any opinion whatsoever on the part of Research Square concerning the legal status of any country, territory, city or area or of its authorities, or concerning the delimitation of its frontiers or boundaries. This map has been provided by the authors. 


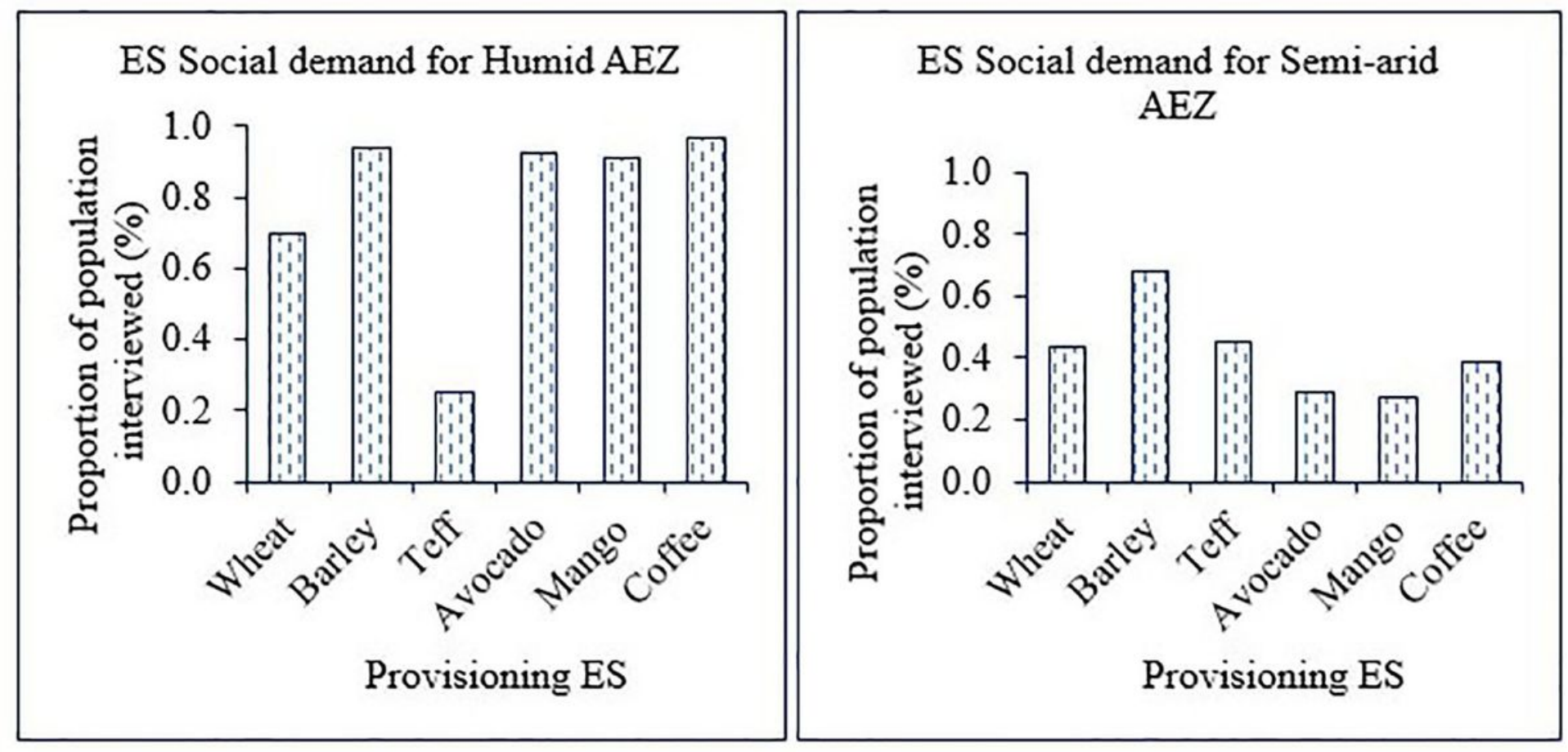

Figure 5

Social perception of the provisioning ecosystem goods of the study region

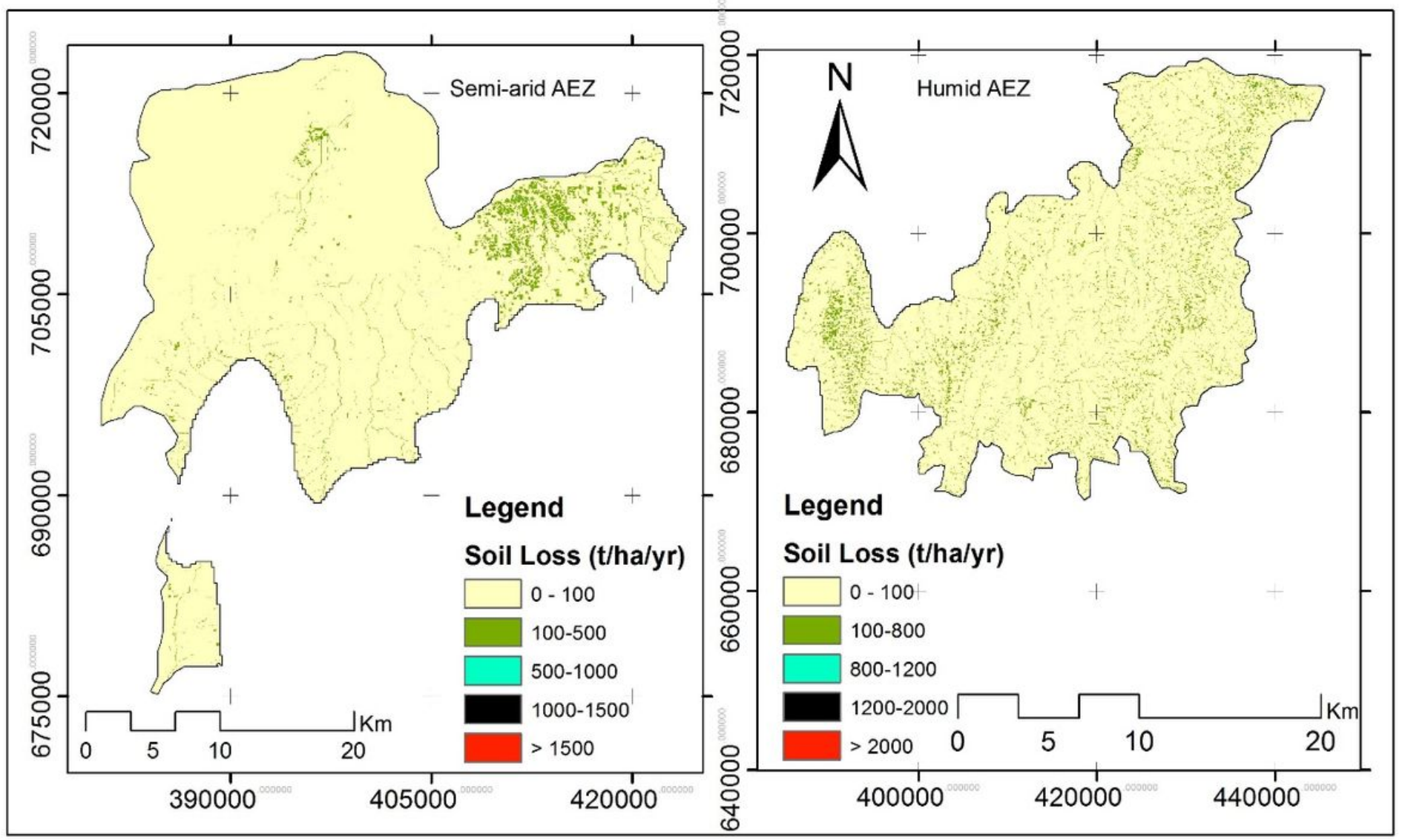

Figure 6 
Spatial distribution of soil loss ( $\mathrm{t} / \mathrm{ha} / \mathrm{years})$. Note: The designations employed and the presentation of the material on this map do not imply the expression of any opinion whatsoever on the part of Research Square concerning the legal status of any country, territory, city or area or of its authorities, or concerning the delimitation of its frontiers or boundaries. This map has been provided by the authors.

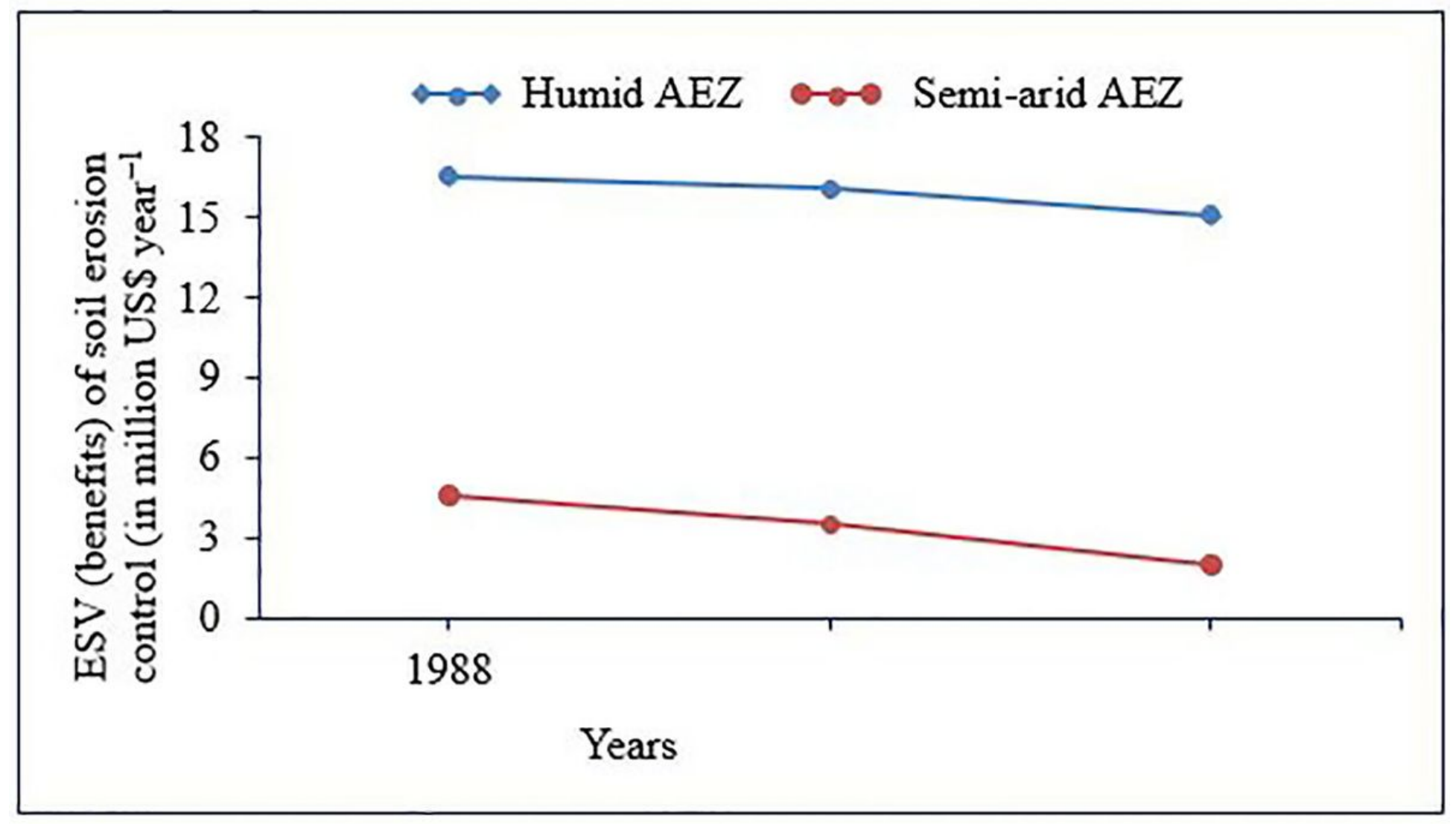

Figure 7

Annual estimated value of soil erosion control (ESVf in million US\$ year-1) under different reference years and their changes (1988 to 2018) in the study region. 


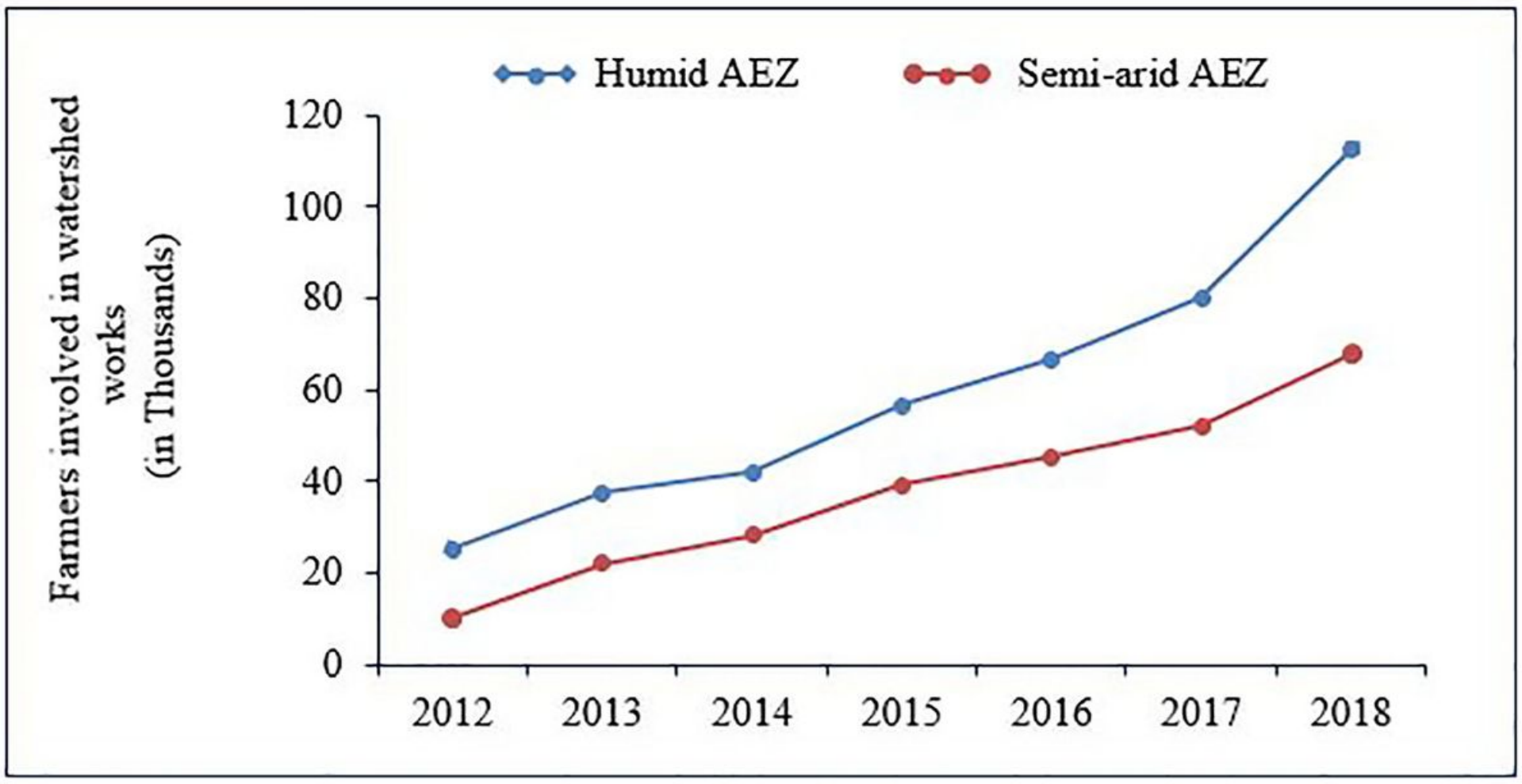

Figure 8

Number of smallholder farmers participated in soil erosion control practices. Source: agricultural office at kebele level. 


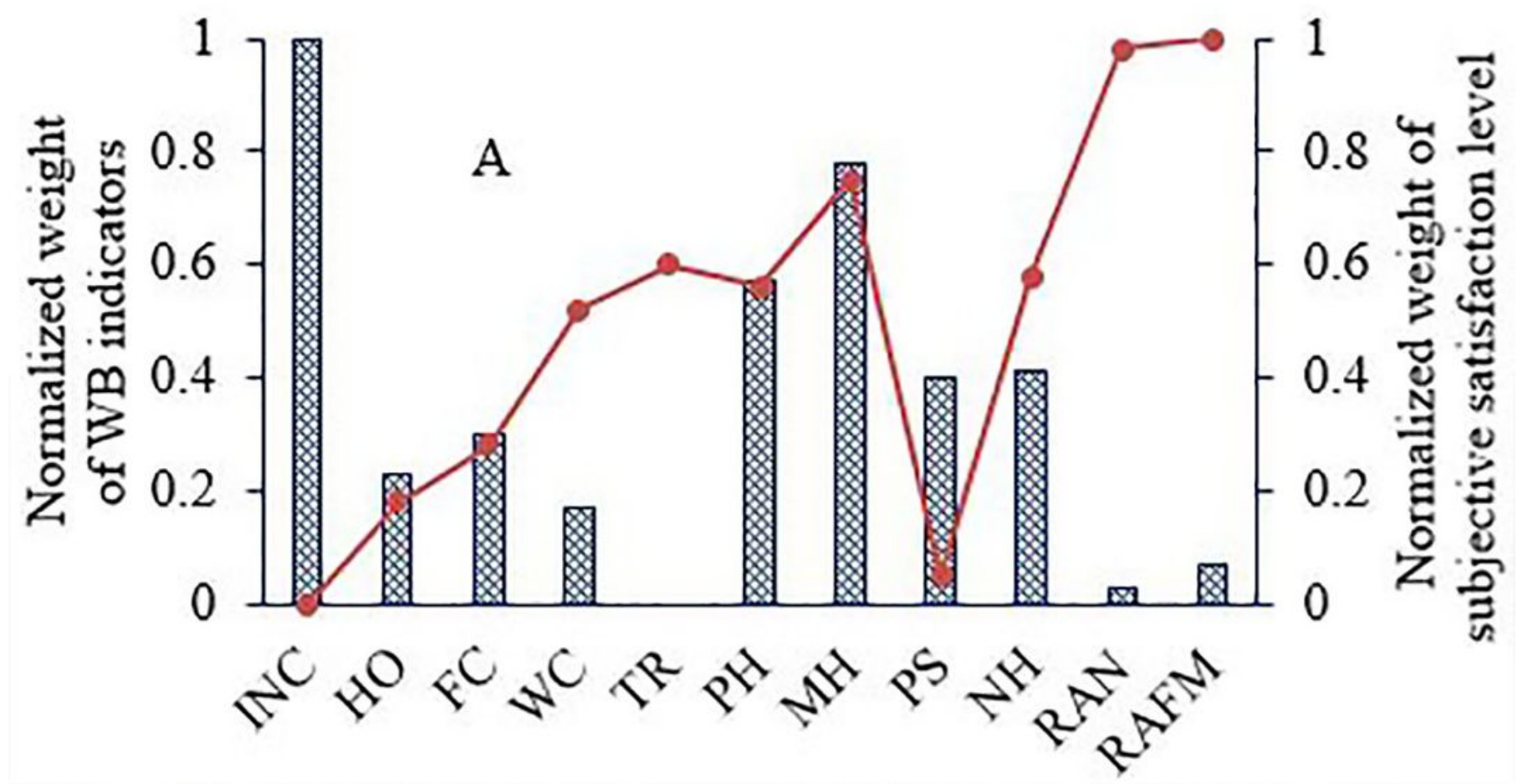

Weight of WB indicators $\rightarrow$ Subjective Satis faction level

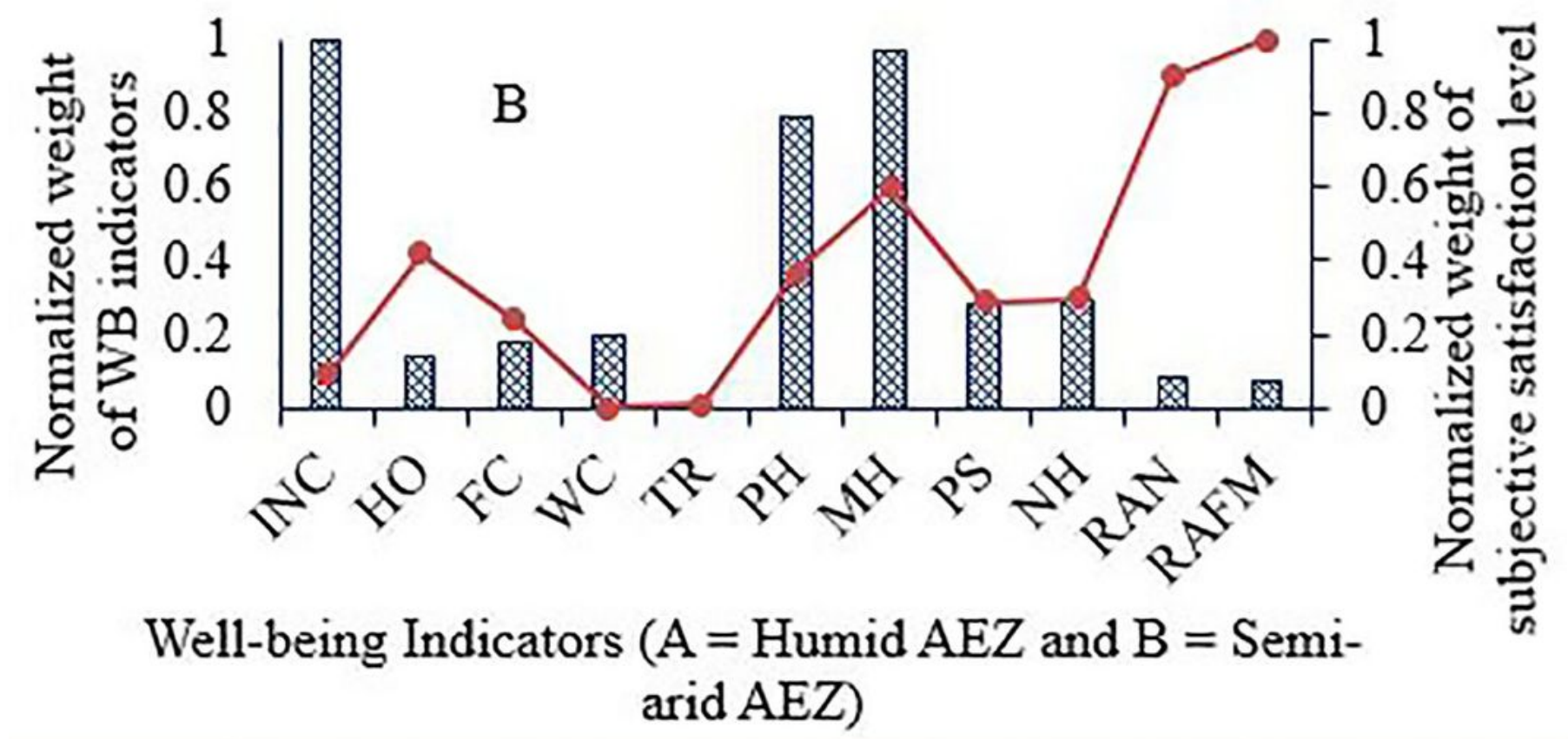

Figure 9

The weights of smallholder farmers' wellbeing indicators and subjective wellbeing satisfaction level of the study region. Note: INC: Income; HO: Housing; FC: Food consumption; WC: Water consumption; TR: Transportation; PH: Physical health; MH: Mental health; PS: Public security; NH: Natural hazard; RAN: Relationship among neighbour and RAFM: Relationship among family members. 


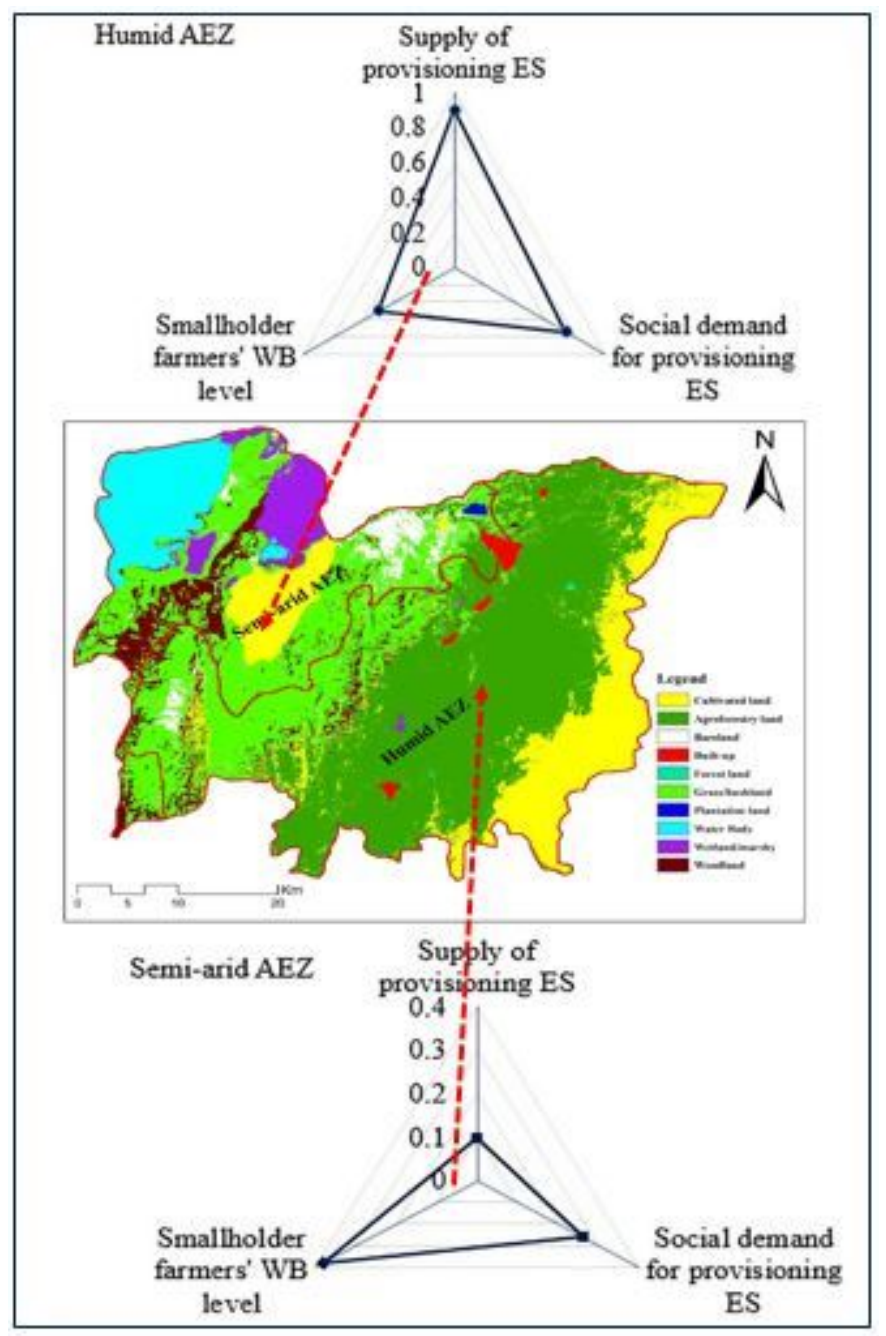

\section{Figure 10}

Radar diagrams that show the relationships between ES and smallholder farmers' wellbeing in humid and semi-arid AEZ. Note: The designations employed and the presentation of the material on this map do not imply the expression of any opinion whatsoever on the part of Research Square concerning the legal status of any country, territory, city or area or of its authorities, or concerning the delimitation of its frontiers or boundaries. This map has been provided by the authors. 


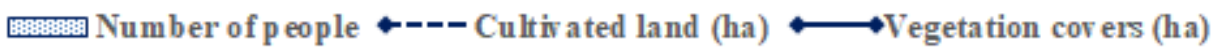
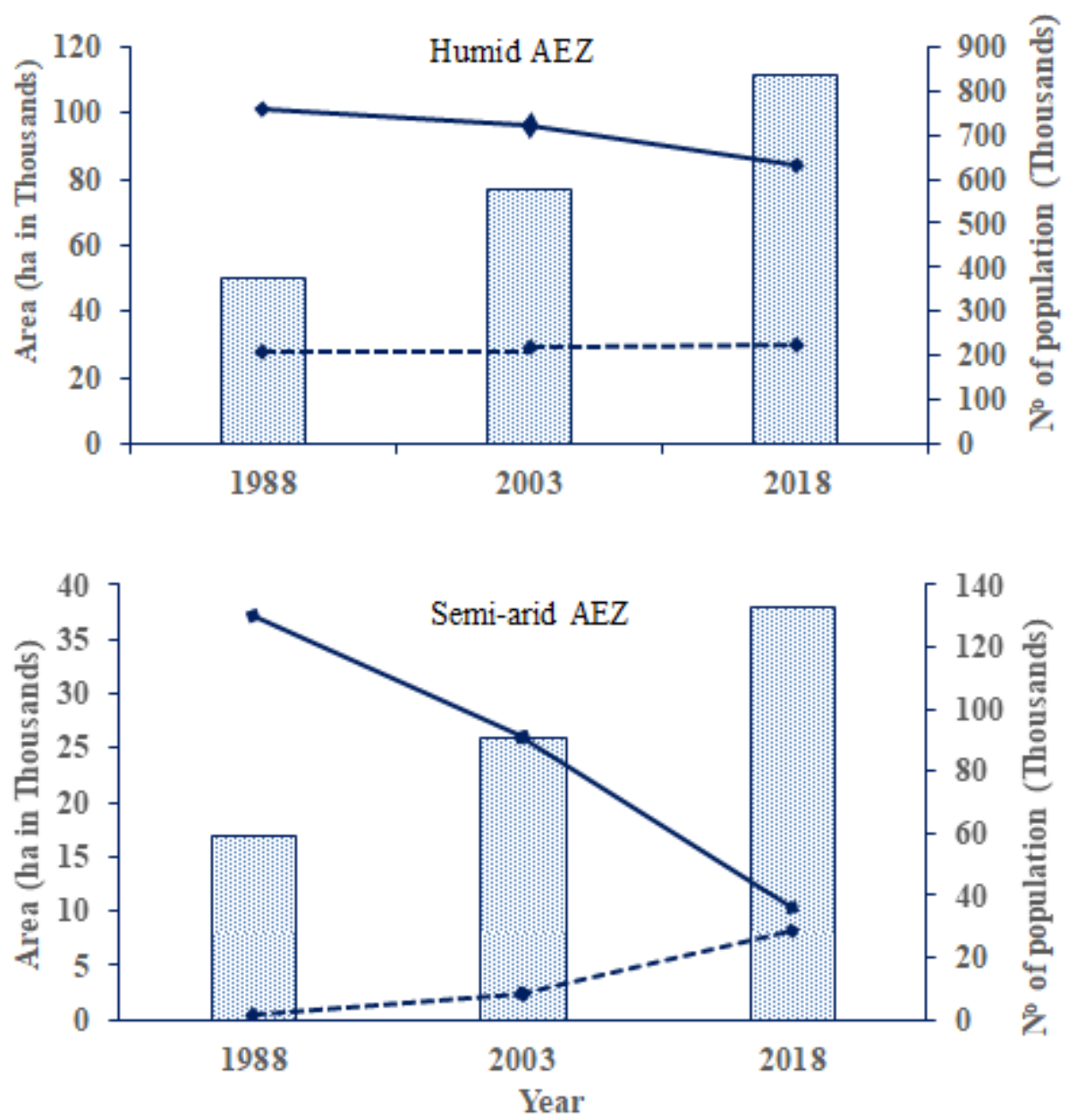

Figure 11

Number of population, vegetation covers (ha), and cultivated land (ha) of humid and semi-arid agroecological zones.

\section{Supplementary Files}

This is a list of supplementary files associated with this preprint. Click to download.

- SupplementaryMaterial.docx 